\title{
Intelligent Pubescent Oak Forests (Quercus Pubescens Wild.) From Dobroudja Plateau, Romania
}

\author{
Lucian Dincă $^{1} \&$ Emilia Vechiu ${ }^{1}$ \\ 1 "Marin Drăcea" National Institute for Research and Development in Forestry, Romania \\ Correspondence: "Marin Drăcea" National Institute for Research and Development in Forestry, 13 Cloşca Street, \\ Braşov-500040, Romania. E-mail: dinka.lucian@gmail.com
}

Received: September 27, 2020 Accepted: October 9, 2020 Online Published: October 30, 2020

\begin{abstract}
Dobrudjea Plateau, located in south-east Romania, is characterized by low altitudes, old rocks, a temperatecontinental climate and a silvosteppe and steppe vegetation. Pubescent oak is one of the tree species characteristic for this area. With average dimensions, this tree fulfils numerous ecosystem functions.

The concept of "Climate-Smart Forestry - CSF" is recent and was adapted in this article for the pubescent oak characteristic for this area; clear and measurable criterions were also identified and applies for this species in order to identify the smart stands.

Smart pubescent oak forests represent 3\% of all this specie's stands and are more common in the north part of Dobrudjea Plateau. They are characterized by advanced ages (61-70 years), 20\%-30\% compositions and evenaged structures. The forests are located on relatively small distances from forest roads, at altitudes of $100 \mathrm{~m}-250$ $\mathrm{m}$, and on west and east expositions.

The present study has showed that smart pubescent oak forests can be established by taking into account 14 site (flora, soil or forest type) and stand conditions (pruning, vitality, average diameter and height, functional group and category, litter). The identification of these stands is extremely important for their protection as well as for applying the appropriate silvicultural measures.
\end{abstract}

Keywords: pubescent oak, smart forests, altitude, structure, age

\section{Introduction}

Dobrudjea Plateau occupies $4.3 \%$ (approximately $12.000 \mathrm{~km}^{2}$ ) of Romania's surface and is situated in the country's south-east part. This region is bordered by the Danube in north and west, by the Black Sea in the east, by Danube's Delta in north-east and by the Bulgarian border in south. The area conserves some of the country's oldest relief forms and structures formed on old rocks (green schists, granite), calcar, slate and loess (Popescu N., and Ielenicz M., 2003; Caraivan, G et al., 2011; Prăvălie, R., at al. 2014a). From a morphologic point of view, the studied area is characterized by low altitudes in the center and south-west parts $(89 \%$ are under $200 \mathrm{~m})$, with altitudes over 400 $\mathrm{m}$ located in the north-part, namely in Măcin Mountains. (Ielenicz M., 2003). From a climatic point of view, this area is situated within the temperate-continental climate. As such, the average annual temperature ranges between $10.7-12.12^{\circ} \mathrm{C}$, while the annual average precipitation quantity is low, under $400 \mathrm{~mm} / \mathrm{an}$, being one of Romania's most arid zones (Manole, D., et al., 2018; Maftei, C. 2015). The most widespread soil types from this area are represented by different chernozems and phaeozems, complemented by luvisols (preluvosol) and cambisols (eutric cambisol) (Marin, I., 2003; Nicolaescu, M., et al., 2009; Spârchez, G. et al., 2017; Dincă, L., et al., 2018). The silvosteppe and steppe vegetation are representative for this area, while the most common forest species are: Quercus pubescens, Fraxinus ornus, Carpinus orientalis, Quercus pedunculifora, and Tilia tomentosa (Marin, I. 2003; Geacu, S. et al., 2018; Onet, A., et al., 2019).

Pubescent oak (Quercus pubescens Willd.) is a Mediterranean species, widespread from South Europe towards north (France, South Germany) and east (Czech Republic, Slovakia and Romania). The species is present in our country in pure stands or mixed with other species, being present in the silvosteppe area as well as scarcely in Transylvania's Basin (Milecka, K., et al. 2004; Şofletea, N., \& Curtu, L. 2007; Wellstein, C., \& Spada, F. 2015). Quercus pubescens Willd. reaches average heights $(15-20 \mathrm{~m})$, and has a thick, black and hard rhytidom. The leaves are characteristic for this species, being tomentose on both sides initially and then only on the back, while the acorn's cup is sessile or shortly pedunculated (Șofletea, N. \& Curtu, L. 2008; Șimonca, V., et al., 2019). The species 
has a rare fructification, at an interval of 5-7 years, which leads to a slow regeneration (Șimonca, V. et al 2019).

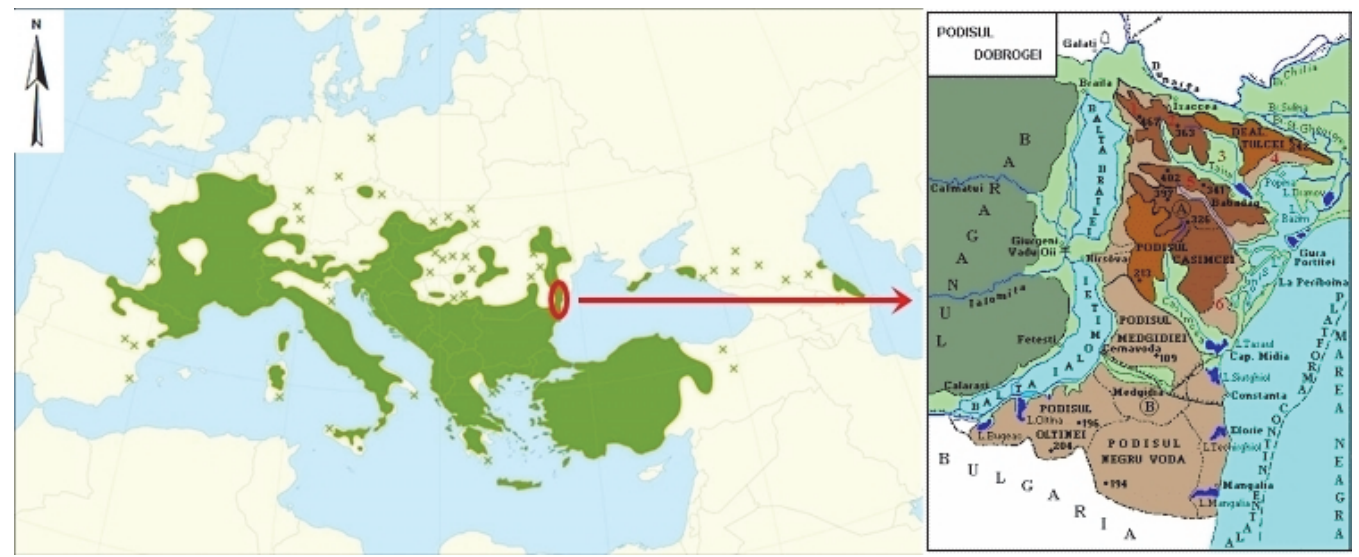

Figure 1. Distribution of pubescent oak

https://en.wikipedia.org/wiki/Quercus_pubescens\#/media/File:Quercus_pubescens_range.svg

Forest stands have numerous ecosystem functions, such as: producing numerous non-wood products (Tudor, C., et al., 2019; Dincă, L. \& Timiș-Gânsac, V. 2020), game and fish species (Ciontu, C., et al., 2020), and forest fruits (Vechiu, E., et al., 2019).

Recently, the most frequent climatic changes are represented by temperature increases and the decrease of precipitations, leading to changes in the forest ecosystems. Romania is one of the countries that has to deal with these climatic changes, so their impact is of major interest for the scientific communities looking to diminish them (Marin, L., et al., 2014; Pravalie, R. et al., 2014b; Constandache, C., et al., 2018; Dincă, L. \& Achim, F., 2019). Over time, many concepts were described and used in evaluating and creating solutions for the management of adapting and diminishing climatic changes. The concept of "Climate-Smart Agriculture" has led to the concept of "Climate-Smart Forestry - CSF" which is still not clearly defined but which concentrates on the following purposes: reducing hothouse gas emissions, reducing stand vulnerabilities and the durable increase of stand productivity (Bowditch, E., et al., 2020; Verkerk, P., et al., 2020). The majority of studies realized up until now have focused on reducing hothouse gas emissions through modelling techniques and their impact on the climate. As such, implementing CSF is necessary in helping managing forests under climatic changes, based on their socioecological purposes (Bowditch, E., et al., 2020; Yousefpour, R., et al., 2018; Nabuurs, G., et al., 2018).

The purpose of this article is to identify and describe smart pubescent oak forests located in Dobrudjea Plateau Romania.

\section{Method}

The inventory and description of Romanian forests is realized every 10 years, when forest management plans are created. These plans contain silvicultural parcels (portions of homogenous forests confined by the field), as well as all environment and stand characteristics. The present article has studied data from 9 forest management plans realized during 1994-2009 (Forest management plans, 1994-2009), from where 1666 pubescent oak stand elements were extracted. Only stands over 40 years were taken into account as the younger one cannot be framed in the smart forests category.

As such, fourteen stand elements (pruning, vitality, average diameter and height, production class, current growth, structure, consistency, production subunit, functional group and subgroup, litter) and site ones (flora, soil or forest type) were studied. Each element has received a grade from 1 to 5 based on the specie's ecological and silvicultural requests, where $1=$ very low; $2=$ low; $3=$ average; $4=$ high; $5=$ very high (Table 1 ). A total grade was obtained by adding all values for a stand, followed by their ordering. 
Table 1. Grades obtained based on the stand's or environment's characteristic

\begin{tabular}{|c|c|c|c|c|c|c|}
\hline \multirow{2}{*}{$\begin{array}{l}\text { Crt. } \\
\text { no. }\end{array}$} & \multirow[t]{2}{*}{ Characteristic } & \multicolumn{5}{|c|}{ Grade } \\
\hline & & 1 & 2 & 3 & 4 & 5 \\
\hline 1 & Pruning & $0.2-0.3$ & 0.4 & 0.5 & 0.7 & 0.6 \\
\hline 2 & Vitality & 5 & 4 & 3 & 2 & 1 \\
\hline 3 & $\begin{array}{l}\text { Average diameter } \\
(\mathrm{cm})^{*}\end{array}$ & $6-12$ & 14 & $16-18$ & $20-22$ & $24-38$ \\
\hline 4 & $\begin{array}{l}\begin{array}{l}\text { Average high } \\
(\mathrm{m})^{*}\end{array} \\
\end{array}$ & $1-6$ & $7-8$ & 9 & 10 & $11-19$ \\
\hline 5 & Production class & 5 & 4 & 3 & 2 & 1 \\
\hline 6 & $\begin{array}{l}\text { Current growth } \\
\left(\mathrm{m}^{3} / \text { year/ha)* }\right.\end{array}$ & 0.1 & 0.2 & 0.3 & $0.4-0.6$ & $0.7-2.9$ \\
\hline 7 & Structure & 1 & 2 & 3 & 4 & \\
\hline 8 & Consistency & $0.3-0.4$ & 0.5 & $0.6 ; 0.9$ & 0.8 & 0.7 \\
\hline 9 & SUP & $\mathrm{Q}$ & $\mathrm{A}$ & $\mathrm{V}$ & $\mathrm{K}$ & $\mathrm{E}, \mathrm{M}$ \\
\hline 10 & $\begin{array}{l}\text { Functional group } \\
+\quad \text { Functional } \\
\text { category }\end{array}$ & $\begin{array}{c}1,3 \mathrm{G} \\
2,1 \mathrm{C}\end{array}$ & $\begin{array}{l}1,3 \mathrm{~A} \\
2,1 \mathrm{~B}\end{array}$ & $1,2 \mathrm{~B} ; 1,5 \mathrm{~L}$ & $1,2 \mathrm{~A}$ & $\begin{array}{l}1,5 \mathrm{C} \\
1,5 \mathrm{D}\end{array}$ \\
\hline 11 & Litter & 1 & 2 & 3 & 4 & 5 \\
\hline 12 & Flora & 53 & $52 ; 74$ & $\begin{array}{c}65 ; 68 ; 72 \\
75\end{array}$ & $61 ; 71$ & 51 \\
\hline 13 & Soil type & $\begin{array}{c}1215 ; 170 \\
39604\end{array}$ & $\begin{array}{l}1210 \\
1701 \\
2205\end{array}$ & 1204 & $1301 ; 1401$ & 1201 \\
\hline 14 & Forest type & 5162 & $\begin{array}{c}5325 \\
5333 \\
8223 \\
8224\end{array}$ & $\begin{array}{c}7531 ; 8112 \\
8521\end{array}$ & 8212 & \\
\hline
\end{tabular}

*For this characteristic, the entire value range was divided in 5 categories, where $1=$ the lowest (ex: average diameter between 10-16 cm), 5 = the largest (ex: current growth higher than $2.8 \mathrm{~m}^{3} / \mathrm{year} / \mathrm{ha}$ ) with grades being given for all categories. The category division was realized to respect the analyzed biometric characteristics, as well as to ensure a balanced division as value number for each category.

The meaning of the terms from Table 2 is rendered below:

Vitality: 1 = very vigorous; 2 = vigorous; 3 = normal; 4 = weak; 5 = very weak.

Structure: $1=$ even-aged stands; 2 = relatively even-aged stands; 3 = relatively uneven-aged stands; $4=$ unevenaged stands.

Production/protection subunits (SUP) (excerpt): A = Regular forest, common assortments: wood for timber, constructions, celluloses; $\mathrm{E}=$ Reservations for the integral protection of nature; $\mathrm{K}=$ Seed reservations; $\mathrm{M}=$ Forests under the extreme conservation regime.

Functional group (GF) and functional category (FCT) (excerpt): 1,2A = Forests located on cliffs, debris, on fields with depth erosion, on fields with a slope higher than 35 degrees or 30 degrees for those situated on flysch, sands or gravels; $1,3 \mathrm{~A}=$ Steppe forests, from the limit between steppe and silvosteppe; $1,3 \mathrm{G}=$ Bodies of dispersed forests, with surfaces under 100 ha, situated in plain areas; $1,5 \mathrm{C}=$ Natural reservations; $1,5 \mathrm{D}=$ Scientific 
reservations; $1,5 \mathrm{~L}=$ Forests from reservation's protection areas (bumper areas); $2,1 \mathrm{~B}=$ Forests meant to produce thick trees of superior quality for timber; $2,1 \mathrm{C}=$ Forests meant to produce average and thin trees for celluloses, rural constructions or other usages.

Litter: 1 = missing litter; 2 = narrow intermittent litter; 3 = narrow continuous litter; $4=$ normal continuous litter; $5=$ thick continuous litter.

Flora: 51 = Asarum-Brachypodium $; 52=$ Carex pilosa $; 53=$ Luzula albida-Carex montana $; 61=$ Asarum-Stellaria; $65=$ Festuca altissima $; 68=$ Luzula albida $; 71=$ Erachypodium-Geum-Pulmonaria $; 72=$ Poa pratensis $; 74=$ Carex brizoides-Agrostis alba; $75=$ Carex riparia-Iris pseudacorus.

Soil type: $1201=$ chernozem; $1204=$ rendzic chernozem; $1210=$ vermic-stagnic chernozem; $1215=$ lithic-rendzic chernozem; 1301 = cambic chernozem; 1401 = phaeozem; $1701=$ rendzina; $1703=$ lithic rendzina; $2205=$ stagnic preluvisol.

Forest type: $5162=$ Holm stands with oriental hornbeam of inferior productivity; 5325= Silvosteppe tug with holm; $5333=$ Dobrudjea tug of interior productivity; $7531=$ Turkey oak-tug of Dobrudjea tug; $8112=$ Pure brown oak on weakly degraded cernoziom with loess substratum; $8212=$ Pubescent oak on profound soil; $8223=$ Pure pubescent oak from the Dobrudjea silvosteppe with superficial soil; $8224=$ Silvosteppe pubescent oak with oriental hotnbeam; $8521=$ Dobrudjea oak tug with brown oak and pubescente oak.

\section{Results and Discussion}

Taking into account the fact that smart forests represent up to $10 \%$ of the total forests from an area, if we order down the grade obtained by each pubescent oak stands from Dobrudjea Plateau, we can consider that this category contains forest with a grade higher than 46 , meaning 46 stands. Unlike smart spruce stands from the Southern Carpathians (Dincă, L., et al., 2019), the pubescent oak ones from Dobrudjea Plateau have a lower percentage similar to alder stands from the Southern Carpathians (Blaga, T., et al., 2019) or manna ash (Fraxinus ornus L.) from Banatului Mountains (Dincă L., et al., 2020).

The following elements can be observed by analyzing certain characteristics of these 46 smart forests (Table 2):

Table 2. Characteristics of the pubescent oak smart forests from Dobroudja Plateau

\begin{tabular}{cccccccc}
\hline Crt. no. & $\begin{array}{c}\text { Forest } \\
\text { District }\end{array}$ & $\begin{array}{c}\text { Age } \\
\text { (years) }\end{array}$ & $\begin{array}{c}\text { Alti } \\
\text { tude }(\mathrm{m})\end{array}$ & Exposition & $\begin{array}{c}\text { Percentage } \\
(\%)\end{array}$ & $\begin{array}{c}\text { Struc- } \\
\text { ture }\end{array}$ & $\begin{array}{c}\text { Distance } \\
\text { from the road } \\
(\mathrm{km})\end{array}$ \\
\hline 1 & Ciucurova & 70 & 212 & $\mathrm{E}$ & 30 & 1 & 19 \\
\hline 2 & Ciucurova & 80 & 140 & $\mathrm{~N}$ & 30 & 2 & 1 \\
\hline 3 & Babadag & 100 & 695 & $\mathrm{E}$ & 10 & 2 & 1 \\
\hline 4 & Constanta & 50 & 140 & Plane & 50 & 1 & 7 \\
\hline 5 & Babadag & 65 & 220 & Plane & 70 & 1 & 5 \\
\hline 6 & Cerna & 70 & 320 & $\mathrm{SE}$ & 40 & 1 & 48 \\
\hline 7 & Cerna & 70 & 270 & $\mathrm{SV}$ & 40 & 1 & 46 \\
\hline 8 & Ciucurova & 70 & 110 & $\mathrm{~V}$ & 20 & 1 & 2 \\
\hline 9 & Baneasa & 85 & 140 & $\mathrm{E}$ & 90 & 1 & 28 \\
\hline 10 & Ciucurova & 90 & 240 & $\mathrm{~V}$ & 70 & 2 & 20 \\
\hline 11 & Constanta & 50 & 140 & $\mathrm{Plane}$ & 30 & 1 & 9 \\
\hline 12 & Cerna & 60 & 180 & $\mathrm{~S}$ & 30 & 1 & 39 \\
\hline 13 & Babadag & 65 & 120 & $\mathrm{~N}$ & 90 & 1 & 4 \\
\hline 14 & Cerna & 65 & 200 & $\mathrm{E}$ & 20 & 1 & 7 \\
\hline 15 & Babadag & 70 & 120 & $\mathrm{~N}$ & 40 & 1 & 1 \\
\hline 16 & Ciucurova & 70 & 200 & $\mathrm{~S}$ & 70 & 1 & 11 \\
\hline 17 & Ciucurova & 70 & 120 & $\mathrm{~V}$ & 20 & 1 & 3 \\
\hline 18 & Baneasa & 85 & 140 & $\mathrm{E}$ & 90 & 1 & 27 \\
\hline 19 & Ciucurova & 90 & 220 & $\mathrm{E}$ & 100 & 1 & 6 \\
\hline 21 & Ciucurova & 90 & 180 & $\mathrm{~V}$ & 100 & 1 & 10 \\
\hline Babadag & 100 & 140 & $\mathrm{Plane}$ & 30 & 1 & 2 \\
\hline Cerna & 60 & 205 & $\mathrm{SE}$ & 30 & 1 & 42 \\
\hline
\end{tabular}




\begin{tabular}{cccccccc}
\hline 23 & Babadag & 65 & 120 & V & 20 & 3 & 5 \\
\hline 24 & Cerna & 70 & 200 & SV & 30 & 1 & 32 \\
\hline 25 & Cerna & 70 & 230 & SE & 40 & 1 & 44 \\
\hline 26 & Cerna & 70 & 220 & V & 30 & 1 & 41 \\
\hline 27 & Cerna & 70 & 200 & NE & 20 & 1 & 46 \\
\hline 28 & Macin & 75 & 420 & Plane & 30 & 1 & 24 \\
\hline 29 & Niculitel & 80 & 230 & Plane & 70 & 1 & 5 \\
\hline 30 & Ciucurova & 90 & 230 & SV & 60 & 1 & 15 \\
\hline 31 & Babadag & 100 & 155 & E & 10 & 3 & 8 \\
\hline 32 & Cerna & 60 & 210 & S & 20 & 1 & 5 \\
\hline 33 & Cerna & 60 & 185 & SE & 20 & 1 & 52 \\
\hline 34 & Cerna & 60 & 180 & SE & 30 & 1 & 43 \\
\hline 35 & Cerna & 60 & 250 & SE & 20 & 1 & 9 \\
\hline 36 & Babadag & 65 & 140 & N & 70 & 3 & 8 \\
\hline 37 & Babadag & 65 & 185 & E & 30 & 1 & 17 \\
\hline 38 & Constanta & 70 & 100 & V & 20 & 2 & 25 \\
\hline 39 & Ciucurova & 70 & 200 & S & 30 & 2 & 8 \\
\hline 40 & Niculitel & 75 & 300 & NE & 50 & 1 & 12 \\
\hline 41 & Niculitel & 75 & 220 & E & 100 & 1 & 26 \\
\hline 42 & Baneasa & 85 & 140 & S & 80 & 1 & 27 \\
\hline 43 & Baneasa & 85 & 135 & V & 60 & 1 & 28 \\
\hline 44 & Constanta & 90 & 230 & NE & 90 & 1 & 7 \\
\hline 45 & Ciucurova & 90 & 230 & S & 100 & 1 & 1 \\
\hline 46 & Niculitel & 100 & 270 & V & 60 & 2 & 5 \\
\hline & & & & & &
\end{tabular}

From a geographic distribution point of view, smart pubescent oak forests are present especially in Cerna, Ciucurova and Babadag Forest Districts, but can also be found in lower percentages in Constanta, Baneasa and Niculitel. However, these stands miss entirely in Cernavoda and Casimcea Forest Districts (fig. 2).

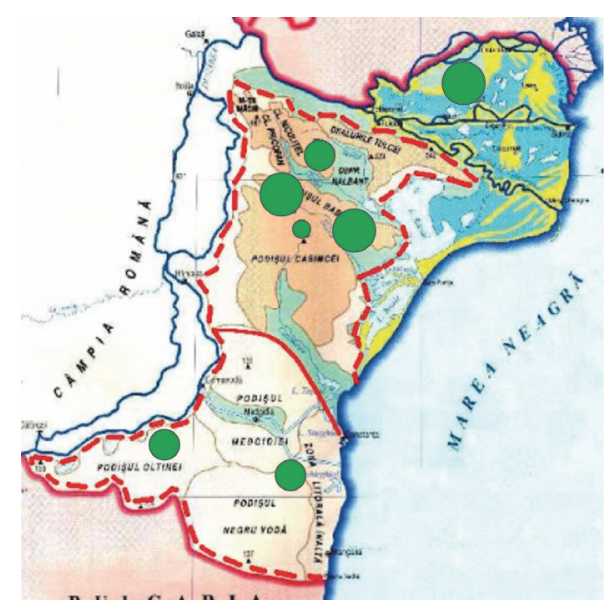

Figure 2. Distribution of smart pubescent oak forests in Dobroudja Plateau

The age of these smart forests is varied, ranging between 50 and 100 years. Very advanced old ages are not a characteristic of smart forests. The majority of these stands are situated between the 61-70 years category. 


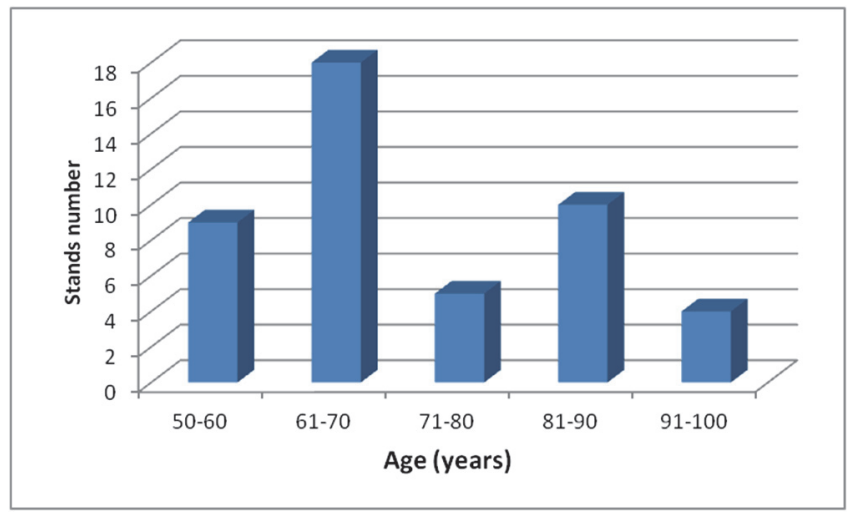

Figure 3. Distribution of smart pubescent oak forests in Dobroudja Plateau on ages

As an altitudinal distribution, these stands are situated between 100 and $695 \mathrm{~m}$, mainly at altitudes of 100 and 250 m (fig. 4).

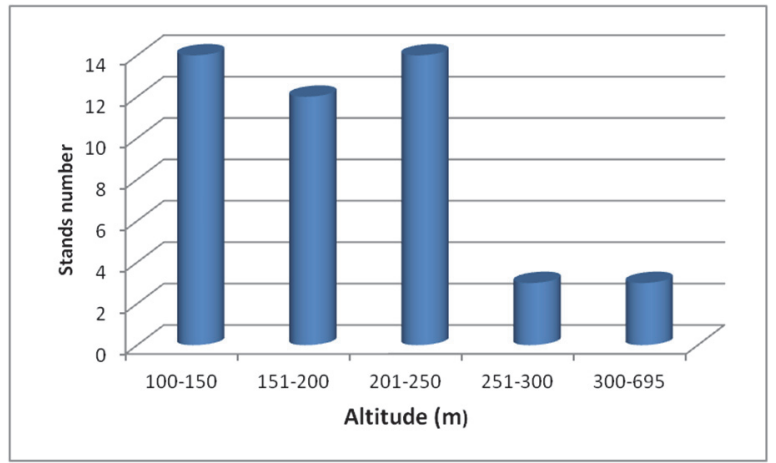

Figure 4. Distribution of smart pubescent oak forests in Dobroudja Plateau on altitudes

The west and east expositions are characteristic for smart pubescent oak forests. As the species is xerophyte, it develops well on sunny expositions and is less present on shadowed slopes (Figure 5).

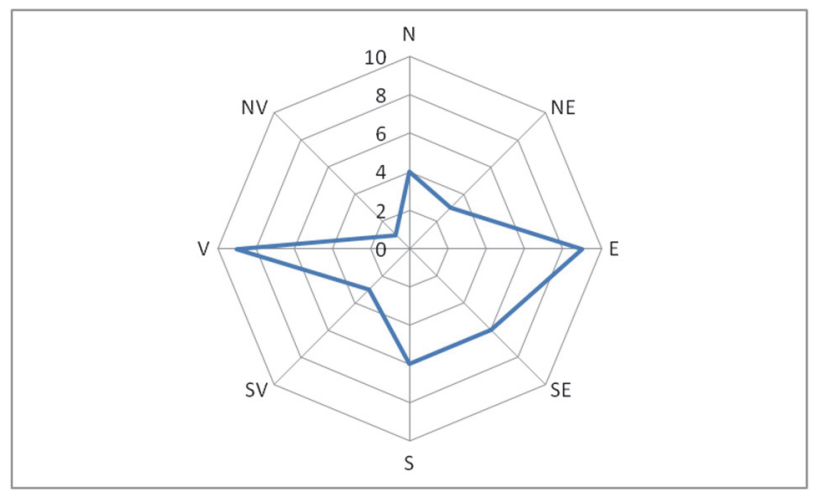

Figure 5. Distribution of smart pubescent oak forests in Dobroudja Plateau on expositions

Smart pubescent oak stands are very rarely pure stands. As such, the species enters in the stand composition in different percentages, with the most common one being of 20-30\% (Figure 6). 


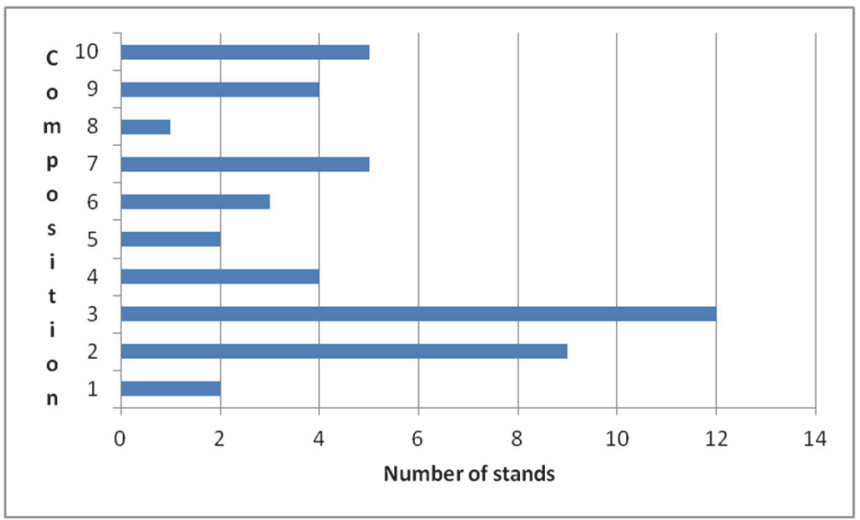

Figure 6. Participation percentage in stands compositions of smart oak forests from Dobroudja Plateau

The structure of these stands is mainly even-aged ( $80 \%)$, with only $13 \%$ of them being relatively even-aged and even fewer (7\%) relatively uneven-aged (Figure 7).

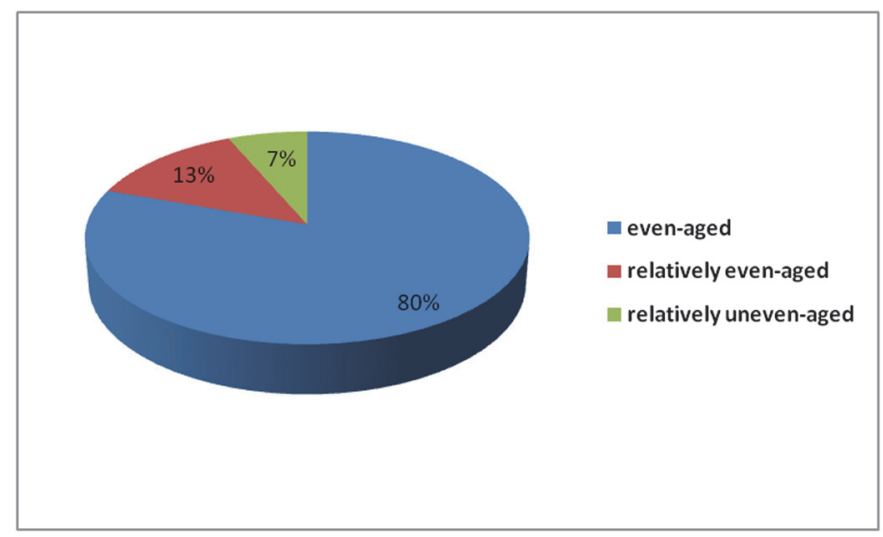

Figure 7. Distribution of smart pubescent oak forests in Dobroudja Plateau on structure categories

In regard with the distance between these stands and existent roads, the stands are situated at relatively small distances from the roads (between $1 \mathrm{~km}$ and $11 \mathrm{~km}$ ), with the exception of stands from Cerna Forest Districts (which are situated in the Danube Delta, so at considerable distances from the roads).

\section{Conclusions}

Due to the difficult ecological conditions on which they vegetate, pubescent oak stands from this area can be situated in the smart forests category only in a percentage of 3\%. This number is lower than that of stands formed of Romania's main species (spruce), but is similar with disseminated species (alder).

Smart pubescent oak forests are present especially in Dobroudja Plateau north part but can also appear in the south part, although they lack entirely from the central area. These stands are characterized by ages between 50 and 100 (mainly between 61-70 years), altitudes between 100 and $250 \mathrm{~m}$, west and east expositions, $20 \%$ and 30\% oak participation percentages, even-aged structures and relatively small distances from forest roads.

Knowing the stand and environment characteristics of smart pubescent oak stands is extremely important for identifying these stands and for establishing the silvicultural measures needed for obtaining a larger number of these stands as well as for protecting the existing ones.

\section{References}

Blaga, T., Dinca L., \& Pleșca, I. M. (2019). How can smart alder forests (Alnus glutinosa (L.) Gaertn.) from the Southern Carpathians be indentified and managed. Romania: Scientific papers series Management, Economic Engineering in Agriculture and Rural Development, 19(4), 29-35.

Bowditch, E., Santopuoli, G., Binder, F., Rio, M. D., La Porta, N., Kluvankova, T., ... \& Pretzsch, H. (2020). What 
is Climate-Smart Forestry? A definition from a multinational collaborative process focused on mountain regions of Europe. Ecosystem Services, 43, 101113. https://doi.org/10.1016/j.ecoser.2020.101113

Caraivan, G., Dinu, I., Fulga, C., \& Popescu, D. (2011). Climate change and the hydrogeologic framework in Constanta city, South Dobrogea, Romania (pp. 259-265). Climate Change and its Effects on Water Resources Springer, Dordrecht. https://doi.org/10.1007/978-94-007-1143-3_28

Ciontu, C. I., Chisăliță, I., \& Dincă, L. (2020). Study concerning the evaluation of game and fish species from Caraş-Severin County. Romania: Annals of West University of Timişoara, ser. Biology, 23(1), 21-28.

Constandache, C., Dinca, L., Tudose, N. C., \& Panaitescu, C. (2018). Protecting surface water resources through silvicultural methods (pp. 276-284) International Symposium "The Environment and the Industry", SIMI, Proceedings book Section Pollution Assessment \& Management Systems. http://doi.org/10.21698/simi.2018.fp33

Dincă, L., Badea, O., Guiman, G., Braga, C., Crisan, V., Greavu, V., Murariu, G., \& Georgescu, L. (2018). Monitoring of soil moisture in Long-Term Ecological Research (LTER) sites of Romanian Carpathians. Annals of Forest Research, 61(2), 171-188. https://doi.org/10.15287/afr.2018.1188

Dincă, L., \& Achim, F. (2019). The management of forests situated on fields susceptible to landslides and erosion from the Southern Carpathians. Romania: Scientific papers series Management. Economic Engineering in Agriculture and Rural Development, 19(3), 183-188.

Dincă, L., Murariu, G., Iticescu, C., Budeanu, M., \& Murariu, A. (2019). Norway spruce (Picea Abies (L.) Karst.) smart forests from Southern Carpathians. International Journal of Conservation Science, 10(4), 781-790.

Dincă, L., Vechiu, E., \& Oneț, A. (2020). Can we identify manna ash (Fraxinus ornus L.) "smart forests" in Banatului Mountains? Romania: Natural Resources and Sustainable Development, 10(1), 91-100. http://doi.org/10.31924/nrsd.v10i1.047

Dincă, L., \& Timiș-Gânsac, V. (2020). The usage of non-wood forest products - Culinary and artisanal traditions in Romania. Sustainable Development Research, 2(1), 50-57. https://doi.org/10.30560/sdr.v2n1p50

Forest Management plans (1994-2009). Baneasa (2005), Cernavoda (1994), Constanta (2009), Babadag (1994), Casimcea (2007), Niculitel (2001), Cerna (2001), Ciucurova (2004), Macin (1995).

Geacu, S., Dumitraşcu, M., \& Grigorescu, I. (2018). On the biogeographical significance of protected forest areas in Southern Romania. Sustainability, 10(7), 2282. https://doi.org/10.3390/su10072282

Ielenicz, M. (2003). Relieful litostructural din Podişul Dobrogei (pp. 51-58). Analele Universităţii "Valahia" Târgovişte, Seria Geografie.

Maftei, C. (Ed.). (2015). Extreme weather and impacts of climate change on water resources in the Dobrogea region. United States of America. IGI Global.

Manole, D., Jinga, V., Giumba, A. M., Dudoiu, R., \& Cristea, S. (2018, July). Researches regarding new and improved technologies for sunflower and sorghum crops in the context of climate changes in Dobrogea region (pp.). In "Agriculture for Life, Life for Agriculture" Conference Proceedings 1(1), 79-85. Sciendo.

Marin, I. (2003), Peisajele Dobrogei: tipuri, repartitie, culturalitate, vulnerabilitate, (pp. 59-82). Romania. Analele Universităţii București, Facultatea de Geografie.

Marin, L., Birsan, M. V., Bojariu, R., Dumitrescu, A., Micu, D. M., \& Manea, A. (2014). An overview of annual climatic changes in Romania: trends in air temperature, precipitation, sunshine hours, cloud cover, relative humidity and wind speed during the 1961-2013 period. Carpathian Journal of Earth and Environmental Sciences, 9(4), 253-258.

Milecka, K., et al. (2004). Quercus L.-oak. Late Glacial and Holocene history of vegetation in Poland based on isopollen maps (pp. 189-197).

Nicolaescu, M., Lupascu, N., \& Chirila, E. (2009). Land degradation and desertification risk in Dobrogea region. Romania. Environmental Engineering \& Management Journal (EEMJ), 8(4), 911-914. https://doi.org/10.30638/eemj.2009.131

Onet, A., Dincă, L., Grenni, P., Laslo, V., Teusdea, A., Vasile, D., Enescu, R., Crisan V. (2019). Biological indicators for evaluating soil quality improvement in a soil degraded by erosion processes. Journal of Soils and Sediments, 19(5), 2393-2404. https://doi.org/10.1007/s11368-018-02236-9

Popescu, N., \& Ielenicz, M. (2003). Refieful Podișul Dobrogei - caracteristici și evoluție (pp. 5-58). Romania. 
Analele Universității București, Geografie.

Prăvălie, R., Sirodoev, I., Patriche, C. V., Bandoc, G., \& Peptenatu, D. (2014a). The analysis of the relationship between climatic water deficit and corn agricultural productivity in the Dobrogea plateau. Carpathian Journal of Earth and Environmental Sciences, 9(4), 201-214.

Prăvălie, R., Sîrodoev, I., \& Peptenatu, D. (2014b). Detecting climate change effects on forest ecosystems in Southwestern Romania using Landsat TM NDVI data. Journal of Geographical Sciences, 24(5), 815-832. https://doi.org/10.1007/s11442-014-1122-2

Şimonca, V., Roșca, S., Colișar, A., Rebrean, F., \& Bilașco, Ș. (2019). Favourable and Restrictive Factors for Quercus pubescens in the Transylvanian Basin, Evaluated by GIS Techniques. Romania. Notulae Botanicae Horti Agrobotanici Cluj-Napoca, 47(4), 1299-1307. https://doi.org/10.15835/nbha47411624

Şofletea, N., \& Curtu, L. (2007). Dendrologie. Editura Universităţii Transilvania din Braşov, 540 pp.

Sparchez, G., Dinca, L., Marin, G., Dincă, M., Enescu, R. (2017). Variation of eutric cambisols' chemical properties based on altitudinal and geomorphological zoning. Environmental Engineering and Management Journal, 16(12), 2911-2918. https://doi.org/10.30638/eemj.2017.300

Tudor, C., \& Dincă, L. (2019). The main categories of non-wood forest products from Vrancea County. Research Journal of Agricultural Science, 51(4), 211-217. https://www.rjas.ro/paper_detail/3024

Vechiu, E., \& Dincă, L. (2019). Forest fruits from Sibiu County. Research Journal of Agricultural Science, 5(3), 163-168. Retrieved from https://www.rjas.ro/paper_detail/3083

\section{Copyrights}

Copyright for this article is retained by the author(s), with first publication rights granted to the journal.

This is an open-access article distributed under the terms and conditions of the Creative Commons Attribution license (http://creativecommons.org/licenses/by/4.0/). 